\begin{tabular}{|c|c|c|}
\hline Received: March 2019 & Accepted: April 2019 & Published: April 2019 \\
\hline \multicolumn{2}{|c|}{ Article DOI: http://dx.doi.org/10.24903/sj.v4i1.274 } \\
\hline
\end{tabular}

\title{
Mapping Schools' Strength in Inclusive Education Learning for Building Language Competence in Wetland Ecological Awareness
}

\author{
Moh. Yamin \\ Lambung Mangkurat University \\ moh_yamin@ulm.ac.id \\ Utomo \\ Lambung Mangkurat University \\ utomo.plb@ulm.ac.id
}

\begin{abstract}
This research aims at mapping schools' strength in facilitating the inclusive education learning towards for building language competence in wetland ecological awareness. It is descriptive in qualitative approach. The respondent is teachers in three schools, namely state junior high school 13, 15, and 21 in Banjarmasin. The instrument used is questionaire and interview. The results state that there has been positive teachers' perception about inclusive education dealing the adaptation of the curriculum and/or individual learning plans, teaching and learning materials for learners with special needs, communication skill under the characteristics of children with special needs, and the minimum completeness criteria for children with special needs that are in accordance with their abilities and needs. There is also positive perception about Banjarmasin as the peat area, loving the river as the manifestation of taking care of the river, and the ecological education to maintain and keep Banjarmasin as a city of a thousand rivers inserted in certain subject. However, all teachers do the task based on limited knowledge and experience. Strengthening language competence so that the teacher can interact with the learners for special needs inspite of limited knowledge and experience should be conducted.
\end{abstract}

Keywords: inclusive education, learning, wetland, ecological awareness, and language competence 


\section{INTRODUCTION}

The main goal of education is to create the qualified human resources. School as the main component in conducting the qualified education should be defined as the education institution to be responsible for celebrating the qualified education process. The qualified education process means that there is positive atmosphere between the teacher and students in learning activity. The teacher delivers the material; the students pay attention very much. The interaction in the learning class is built to move and to share the knowledge from the teacher to students. The interactive learning model is based on the teacher-learner and learner-learner paradigms that replicate real-life situations and include activities, such as learners' interaction with each other, exchange of information, role-playing, joint problem-solving (Kononova A. \& Pollak, E. A., 2013) .

It means that in interactive class, everything dealing with the teaching and learning activity should be well designed and planned to achieve the goal. Interactive class as the model of learning offers the learning model in which the learners have the process in education. Therefore, education should be meant as the humanistic effort to build the selfidentity civilized and dignified. Education is the process to produce the qualified human resources contributing towards civilization building. Civilization building is the ideal building on how human resources are becoming, not being. Dealing with education as the way of educating, it is important to state that any schools have the task to celebrate the education process in order to drive the learners meaningful. School is the education space so that the learners can interact and build their lives for making them meaningful. School is the place to move the learners learn to think, learn to make the paradigm, and so on. School can be made analogy as the place for training and practicing, learning to respond the life fact, and learning to analyze the life problems, and so on.

Dealing with the position of school that is strategic in forming the learners' life skill, it is necessary to mention that school with the environment should be understood as the package of document having the significant impact for learners' change. Leaners' change is dealing with their position, who are able to be with the environment. It means that the good learning is based on the environment as the source of learning. When the learners can interact and communicate with the environment as the source of learning, it will contribute towards how the learners undergo the education process. Because Banjarmasin in which the learners live and interact at school is categorized as the wetland area, it is firm to state that the learning process, the learning model, the learning program, and the learning experience the 
learners have in school environment will determine the learning path for the next step. Banjarmasin as the wetland in which the learners get everything should be viewed to be able to open the new perspective of learning and understanding. In this context, the learners for special need are the focus of this research in which this research aims at mapping schools' strength in facilitating the inclusive education learning for building language competence in wetland ecological awareness. The significance of this study is intended to develop the language teaching learning orientated to inclusive education in wetland ecological awareness. By developing such language teaching learning concept, language curriculum at school supports the goal of learning for building language competence dealing with inclusive education in wetland ecological awareness.

Principally, the schools' strength in implementing the inclusive education should get the main attention that there will give the strong effect for the learners' activity at school, especially for the learners with the special needs. It means that the collective understanding about inclusive education should be formed at first before discussing it in more detail. It must be defined as the process of responding the diversity of children through enhancing participation in classrooms and reducing exclusion from education (UNESCO, 2007). In detail explanation, inclusive education provides all learners in a classroom to learn together and to do the learning process collectively. In the classroom, all learners have the same right to get the access for education so that the teachers should treat all in the same manner. Learning is the need for all in learning and all learners should be treated in the same way to be able to learn together. Inclusive education should be meant as the way of facilitating every child to get the qualified education. The education mechanism of inclusive education is based on children enrolled in schools, but are excluded from learning. They need the special treatment because of the need itself. However, those students require the specialized environment in which the teacher should design the learning environment as friendly as possible towards the learners' need for special needs (Khan K.I. Ahmed \& L.Ghaznavi, 2012) Therefore, in context of inclusive education, everyone in the school has a role to play to access the education treatment, but teachers are the most important players in the provision of inclusive education (McDonnell \& Hardman, 1989). It means that treating all learners in diversity of abilities is included in inclusive education.

The position of teachers is significant in strengthening the inclusive education class, so the learners become enthusiastic. Build capacity and positive attitude of teachers towards inclusive education is important to do (Rose, 2001). Therefore, the teachers' attitude towards 
the learners with special needs in the classroom is very important for inclusive education; however, attitude of the teachers and educators are very complex to measure (Fakolade, O. A. Adeniyi \& Tella, 2009). Whatever it is, the main point in implementing the inclusive education at school should be based on the collective spirit that all learners in diversity of abilities should be treated in the same manner because all are leaners and they are coming for learning. There is not discrimination in learning. Language competence also should be had so that the teachers can interact with the learners easily and communicatively. The language competence in teaching is the main capital so that the teachers can be with the learners. Good and communicative language the teachers have and use with the learners will bring the interactive atmosphere so that the goal of learning can be well achieved. Therefore, the teachers' competence in using the communicative language with the learners should be paid attention. The way how the learners with special needs learn is unique and this is the teachers'challenge in teaching. Focus on the child's perspective of what it means to "know language" can lead to insights into the creative, complex and dynamic processes that are part of children's active meaning making with regard to language (Laursen et al., 2016). Therefore, developing oral language skills towards the learners can reflect the developmental capacity itself so that the learners can learn to communicate with and in the environment (Norbury et al., 2016).

\section{METHODOLOGY}

This research is descriptive method in qualitative approach. In conducting the research, it is started by considering the population as the research subject for all junior high schools in Banjarmasin. Because this research is aim at mapping schools' strength in facilitating the inclusive education learning for building language competence in the wetland ecological awareness, the scope of study deals with the teacher's perception of inclusive education dealing with curriculum, lesson plan, minimum completeness criteria; teacher's perception about wetlands; and learning model in applying inclusive education for building ecological awareness towards students with special needs.

The sample used in obtaining the data is 3 schools, namely state junior high school 13, 15, and 21. The respondents involved in this research are teachers; the instrument used is questionnaire and interview. Every teachers as the respondents filled in the questionnaire by answering the questions in multiple choice and essay. Interview was used to strengthen the data gotten in questionnaire. After the data had been tabulated, all data in questionnaire and 
interview were analyzed and described critically. Every finding in data had the same portion to analyze in balancing manner and objectively.

\section{FINDINGS AND DISCUSSION}

\section{Findings}

The state junior high school 13, 15, and 21 are the three schools that are the subjects of the study because they are geographically supportive in answering the research problem where the three schools are in the river area. The three schools, although not schools that formally provide inclusive education, have their own reasons being sampled in order to find out how the concerning schools treat students who have special needs (according to the observations of the teachers) when attending formal education.

\section{The Perception about Inclusive Education}

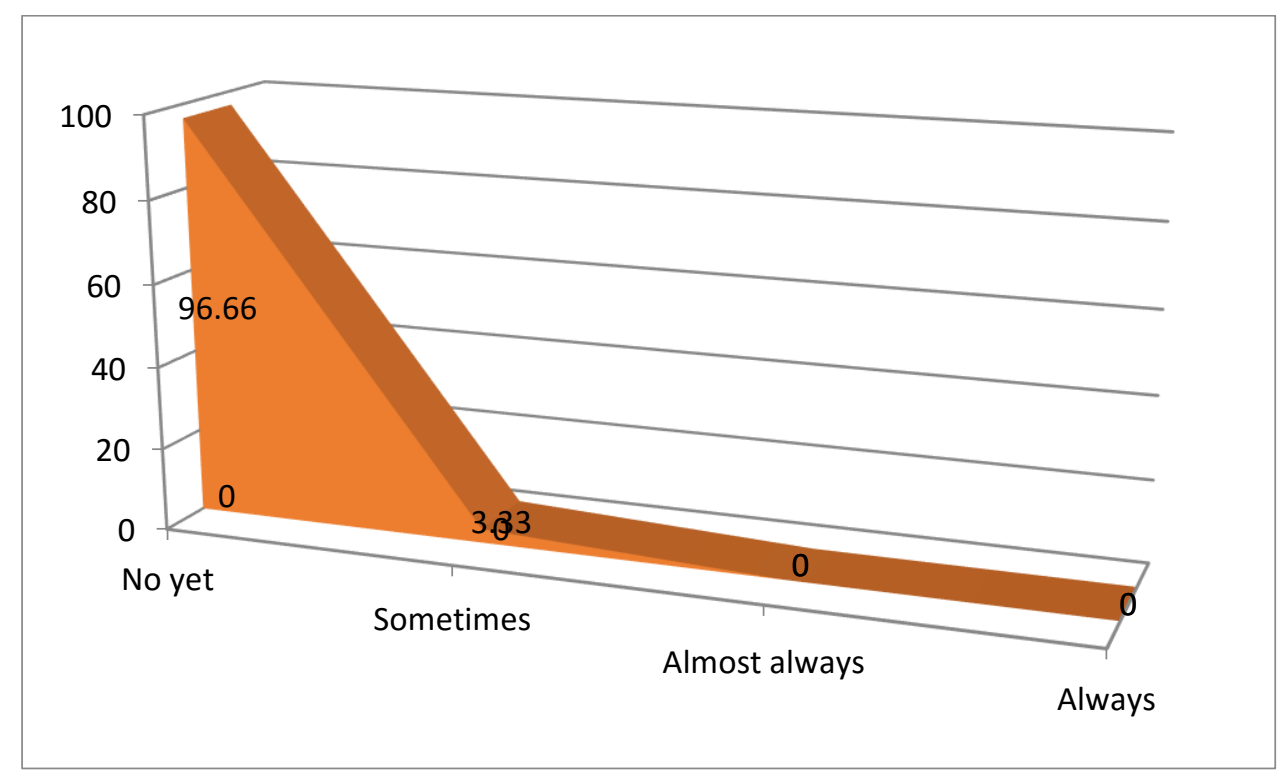

Figure 1. The learning process for children with special needs is carried out in accordance with the adaptation of the curriculum and/or individual learning plans that have been prepared

Figure 1 shows that not all teachers make adjustments or adaptations of curriculum in order to provide the special services to students who have certain special needs. For this reason, the figure above shows that there are only 3.33 percent of the views of the teachers who make curriculum adjustment or adaptation of individual learning plans for each of the students with this particular need. In other words, the teachers sometimes do the curriculum adjustment or adaptation, in accordance with the limits of their knowledge. The learning process for children with special needs is implemented with much limitedness. 


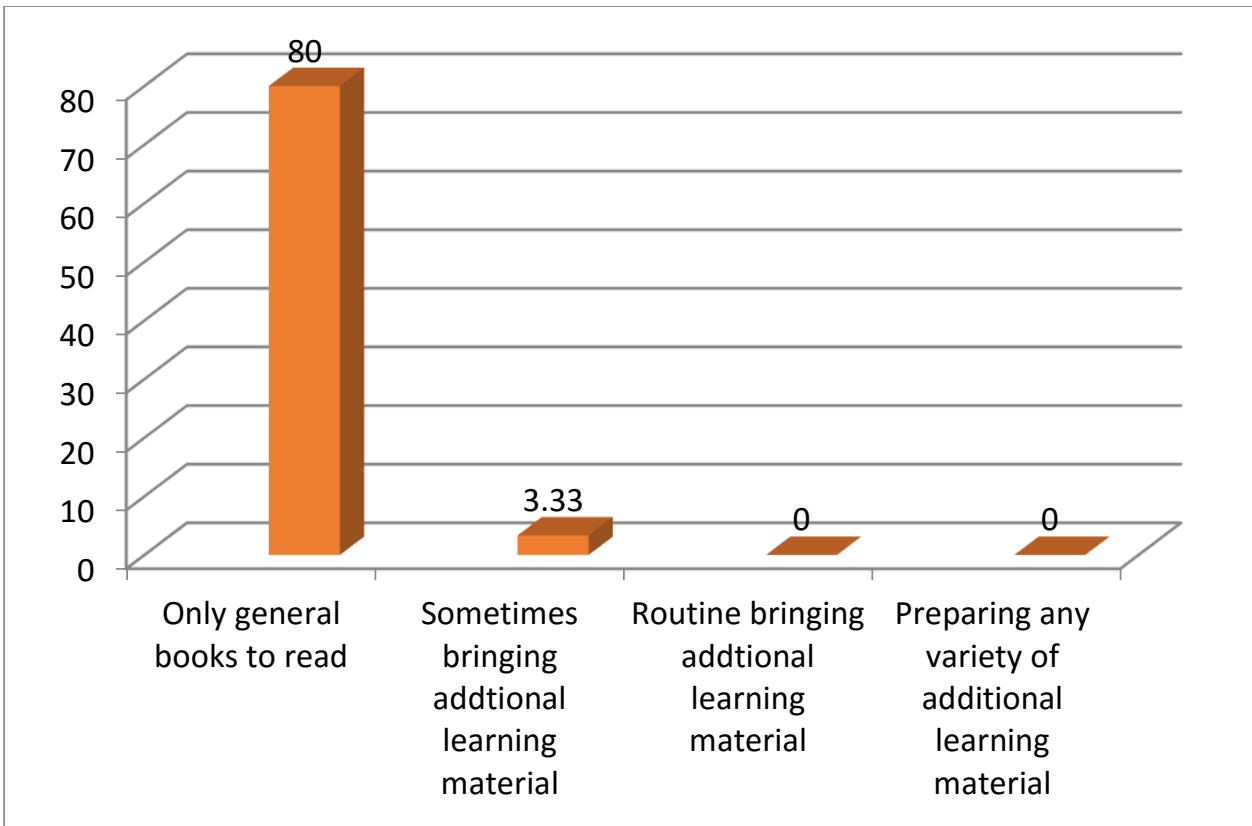

Figure 2. The teacher provides teaching and learning materials that suit the capabilities and needs of children with special needs

Figure 2 also provides a stronger and very basic explanation that not all teachers provide teaching and learning materials that are appropriate to the abilities and needs of children with special needs. There is a view of 3.33 percent of respondents mentioning that they sometimes bring additional learning material into the classroom; it is carried out according to their abilities. While 80 percent of respondents view is only general reading books given and delivered in class. Majority of teachers prefer to use general books because of accessibility to get.

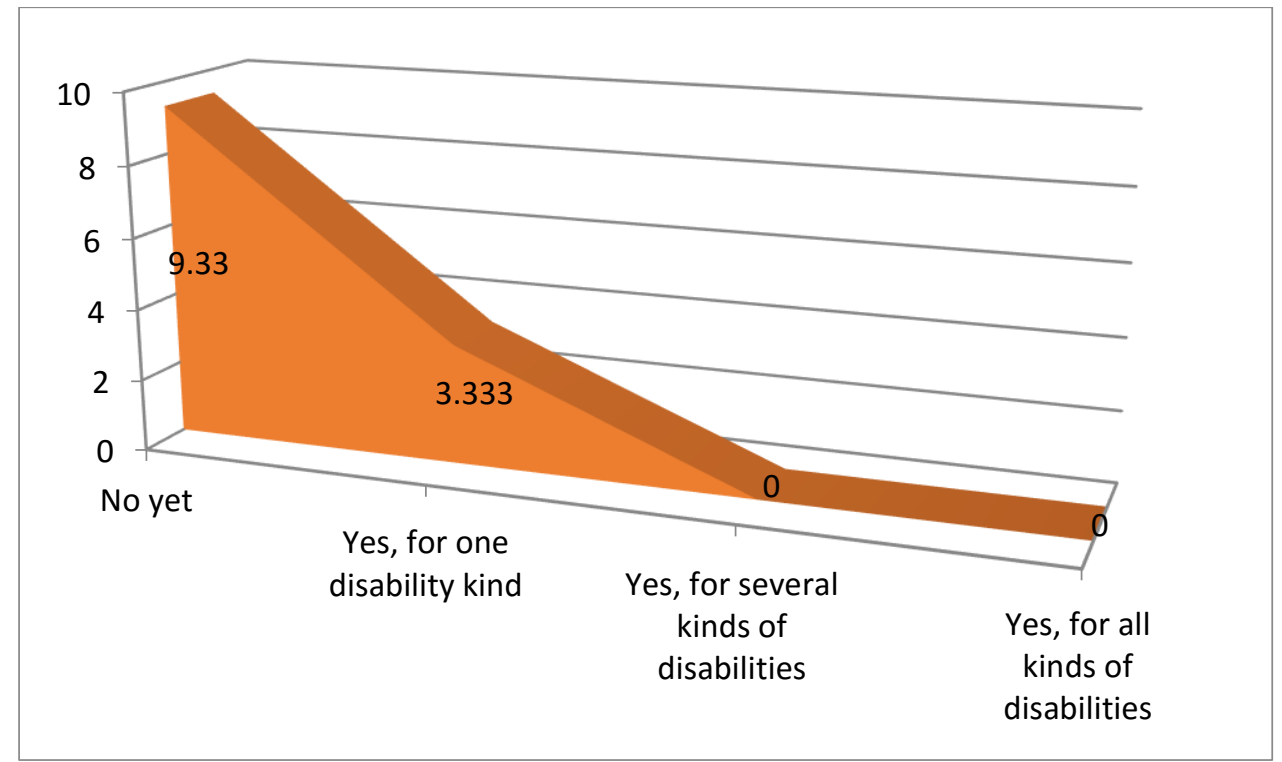

Figure 3. The teacher applies communication skill in accordance with the characteristics of children with special needs 
Figure 3 above illustrates that teachers are only able to apply communication skills that are appropriate to the characteristics of children with special needs for one type of disability, namely 3.33 percent of respondents' views. While 9.33 percent of respondents said that they do not implement communication skill that is in accordance with the characteristics of children with special needs. In their perception, children with special needs should be approaced with different way and the understanding of different way itself is that the teachers should be flexible and understand the students' mood and needs.

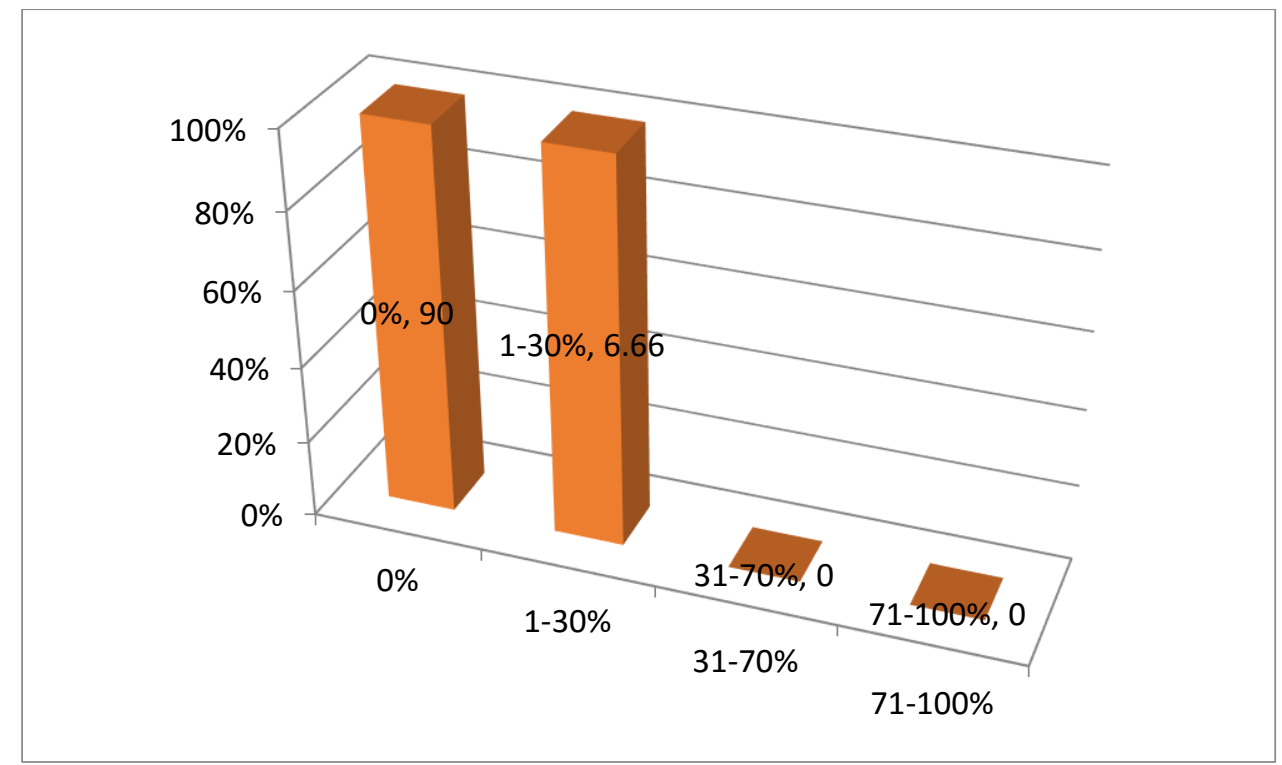

Figure 4. The school has determined the minimum completeness criteria for children with special needs that are in accordance with their abilities and needs

The figure above explains that 6.66 percent of the views of teacher respondents stated that the school had determined the minimum completeness criteria for children with special needs that were in accordance with their abilities and needs, while 90 percent stated that they had not set the minimum completeness criteria for children with special needs who were able to their needs. Every school with different knowledge and experience celebrates the determining of minimum completeness criteria for children with special needs differently because of limitedness of knowledge and experience. 


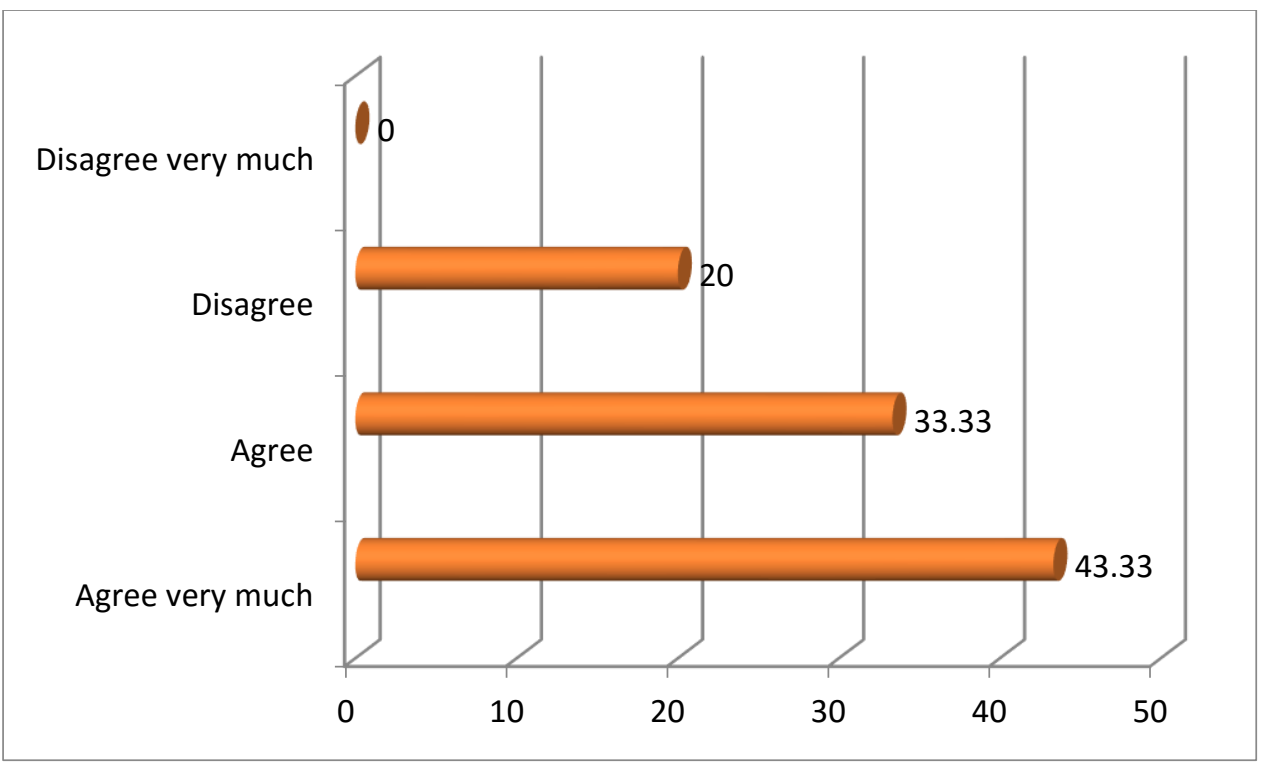

Figure 5. Banjarmasin is a Peat Area

Figure 5 above shows the distribution of views of respondents who referred to Banjarmasin as a peat area. Peat according to some respondents as much as 43.33 states that Banjarmasin is a peat area. 33.33 percent of respondents stated that they agreed that Banjarmasin was a peat area; and 20 percent of respondents think they disagree if Banjarmasin is called a peat area.

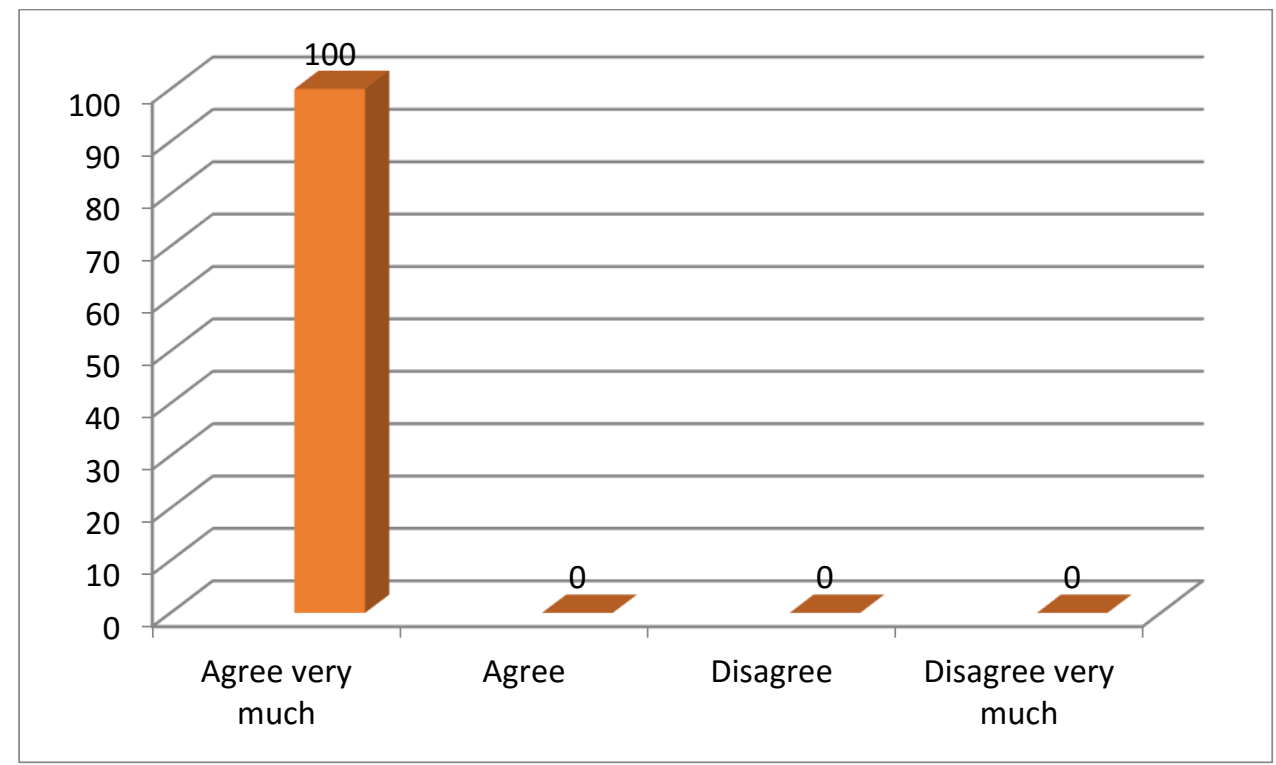

Figure 6. Loving the river same as taking care of the river

Figure 6 relating to loving the same river by taking care of the river is an illustration of the various views of the respondents who stated that loving the river is a necessary thing. Talking about rivers means having to be able to maintain a river. In the view of $100 \%$ of 
respondents, it is very important to love the river as an effort to preserve the river. Their view about taking care of the river is participating to keep the river clean.

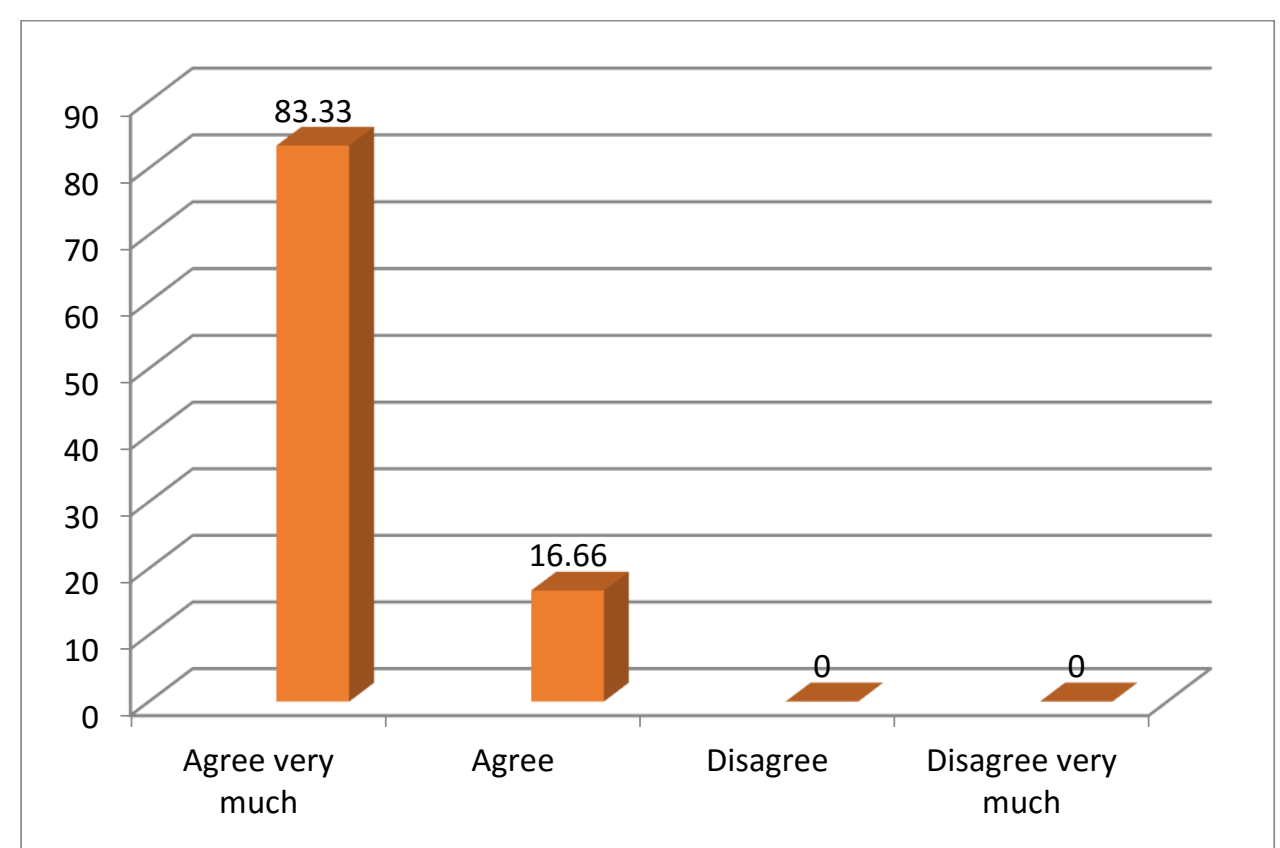

Figure 7. The ecological education to maintain and keep Banjarmasin as a city of a thousand rivers inserted in certain subject is very important to teach in school

Figure 7 tries to imagine what should be done in order to awaken the students through the formal education movement. The views of the respondents about the formalization of ecological development material became very necessary in order to raise awareness of the students to love the river as an inseparable part of the life of the citizens of the city of Banjarmasin and its surroundings. The work of awareness and development of ecological awareness through structured educational material in educational institutions is needed in order to give birth to students who think and view love for the river. Therefore, the view of 83.33 percent of respondents regarding environmental education to maintain and maintain the Banjarmasin as a city of a thousand rivers which is included in certain subjects is very important to be taught in schools.

\section{Discussion}

Based on several findings above, the teachers' ability to provide the special education services to students who have special needs is not optimal due to the limited knowledge and experience in special education services. Therefore, there is a large part of the teacher's view implementing the learning process for children with special needs in limited knowledge and 
experience so that this condition creates the teaching process with minus higly expected goal of effective teaching process.

This also is supported by the detail analysis that the general book for normal students is the material of the teacher in teaching. There are not enough books dealing with learning for special needs. Consequently, the limitedness of reading books for special education, the difficulty of being adjusted to the class where there are also normal students is also the problem causing teachers not to be able to do much in providing reading books for the additional benefit of special students. The limitedness of teachers' knowledge about special education and more complete unavailability in school libraries also become another condition requiring teachers only is able to do what can be done in the classroom for the sake of providing certain additional reading books for special education services.

Therefore, this condition actually explains that teachers with all their limitations try to serve all of their students regardless of their particular status with the best work in order to educate and provide their best education services. The communication skill is expected to be applicable to all those who are normal and who have certain special needs. In the context of organizing education for all, teachers are expected to be able to build good communication towards all of their students in order to provide their best education services. It becomes the main hope even though in reality it cannot always be fully proven with limited knowledge and experience the teachers have.

Relating to the views of the teacher respondents are what they experienced directly in their respective schools become the other entry point that school is required to make the minimum completeness criterial. Nevertheless, the school found some students with the special need and setting the minimum completeness criteria for children with special needs is difficult to implement based on the target and goal. This situation is the new problem that causes the process of teaching and learning for students with special needs hampered.

It happens because the difference of views actually occurs because of differences in views and understanding of peat itself. The differences in views occur because of differences in knowledge and insight they possessed. The differences in views also arise because of the domicile of the respondents so that they subsequently provide views according to where they live. Therefore, peat soil is a land that is always flooded. The position of Banjarmasin with its river identity in the respondents' view is seen differently and varied, according to and adjusting to their respective understandings. This means that whether Banjarmasin is a peat area, this is because the view is different in understanding Banjarmasin as a city of a 
thousand rivers. Such different view creates the difficulty of setting the minimum completeness criteria.

In context of widening the understanding about peat area behalf of inclusive education for building language competence, maintaining the river needs to be interpreted as work to be able to build the ecological awareness so that what is done can open up views about the river itself. (Winarti, A, 2018) state that the environmental awareness of rivers needs to be built with learning approach by inviting students directly to the river. They interact directly with the surrounding river environment so that with such an approach, this can build very high ecological awareness because they become aware and have environmental awareness on their own initiative. They become sensitive to the surrounding environment for their willingness and self-awareness collectively to build ecological commitment.

In their view, this is a systematic effort so that they have a view of living outwardly and inwardly towards their environment in the river. There will be no love for the river when they are not invited to make themselves aware of the importance of maintaining the river. The step is through ecological education that is included in certain subjects. In contexts that are more or less the same as preferences for importance included in certain subjects, the subject of rivers is also needed to open space for awareness of the love of the river. This means that students in this context naturally develop a profile of thinking, thinking, behaving, and acting ecologically in the interests of the river's future in Banjarmasin and its surroundings. Here are several learning models that can be applied in inclusive education for building language competence in wetland ecological awareness:

\section{Inclusive Education Learning Model}

\begin{tabular}{|cl|}
\hline No & \multicolumn{1}{c|}{ Elaboration } \\
\hline 1. & The early ecological education to students is important to do \\
\hline 2. & $\begin{array}{l}\text { The learning materials that contain the importance of river } \\
\text { sustainability, early river cleanliness can be inserted in certain subjects }\end{array}$ \\
\hline 3. & $\begin{array}{l}\text { Making lesson plan is based on the abilities of children with special } \\
\text { needs }\end{array}$ \\
\hline 4. & $\begin{array}{l}\text { Matching the learning method or model of children with special needs } \\
\text { with normal students that needs to be made }\end{array}$ \\
\hline 5. & $\begin{array}{l}\text { It is providing an understanding of wetlands, socializing the function of } \\
\text { wetlands }\end{array}$ \\
\hline 6. & $\begin{array}{l}\text { It is creating strong motivation to learners with special needs in the } \\
\text { learning process of inclusive education }\end{array}$ \\
\hline 8. & $\begin{array}{l}\text { It is inviting the learners with special needs to introduce the river } \\
\text { environment by recreation while searching the rivers in Banjarmasin }\end{array}$ \\
\hline
\end{tabular}




\begin{tabular}{|ll|}
\hline No & \multicolumn{1}{c|}{ Elaboration } \\
\hline 9. & $\begin{array}{l}\text { It is important to habituate the learners to tell what they see and undergo } \\
\text { to build the ecological awareness }\end{array}$ \\
\hline
\end{tabular}

Source: data analysis, 2018

\section{CONCLUSION}

What has explained and discussed above gives the detail explaination that the schools that are implementing the inclusive education learning dealing with wetland ecological awareness are not well prepared because of limitedness of knowledge and experience the teachers have in inclusive education itself. The teachers' teaching performance based on the finding and discussion above in which the teachers commonly teach the learners with special needs without much experience and knowledge show the limited capacity; however; they have worked hard to teach and give the best education service for all. Dealing with the teachers' performance to introduce the learners with building language competence in ecological awareness towards wetlands environment is the series task that requires the strong energy. Creating ecological awareness towards them need the teachers' capacity to be able to be involved directly in students' real life at school. In a word, knowing, identifying their characteristics, and become the main part in their life should be done for achieving the inclusive education learning towards building the wetland ecological awareness. Teaching the learners using the oral language in communicating anything dealing with the environment is necessary to accomplish so that they get the more understanding what are learnt. The pattern of the learners in special needs should be approached with language competence that is understandable and communicative.

\section{BIBLIOGRAPHY}

Fakolade, O. A. Adeniyi, S. O., \& Tella, A. (2009). Attitude of teachers towards the inclusion of special needs children in general education classroom: The case of teachers in some selected schools in Nigeria. International Electronic Journal of Elementary Education, $155-169$.

Khan K.I. Ahmed, \& L.Ghaznavi, A. (2012). Child friendly inclusive education in Pakistan. Insight Plus, 5, 18-20.

Kononova A., \& Pollak, E. A., G. (2013). Interaktivnyi metod otsenki znaniy na osnove primeneniya tekhnologii case study [Interactive Method of Knowledge Assessment Based on the Implementation of the Case Study Technique]. Bulletin of the South Ural State University., 3(5), 93-97. 
Laursen, Pia, Helle, Mogensen, Dahlstrup., \& Naja. (2016). Language Competence in Movement: A Child's Perspective. International Journal of Multilingualism, 13(1), 7491.

McDonnell, A. P., \& Hardman, M. L. (1989). The desegregation of America's special schools: Strategies for change. Research and Practice for Persons with Severe Disabilities, 14(1), 68-74.

Norbury, C. F., Gooch, D., Baird, G., T, C., E., S., \& Pickles., A. (2016). Younger Children Experience Lower Levels of Language Competence and Academic Progress in the First Year of School: Evidence from a Population Study. Journal of Child Psychology and Psychiatry, 57(1), 65-73.

Rose, R. (2001). Primary school teacher perceptions of the conditions required to include pupils with special educational needs. Educational Review, 53(2), 147-156.

UNESCO. (2007). Global Monitoring Report 2008: Education for All by 2015. Will We Make It.

Winarti, A, S. and M. Y. (2018). Designing an integrated learning strategy to develop students' awareness of river environment and science process skills. 